\title{
PENGARUH PRINSIP KERAHASIAAN BANK TERHADAP TINDAK PIDANA PENCUCIAN UANG
}

\author{
Fitriah Faisal \\ Fakultas Hukum, Universitas Haluleo Kendari \\ Email : fitriahfaisal@gmail.com
}

\begin{abstract}
There are two purpose of this research : (1) To know the relation between bank secrecy principle and the emergence of money laundering cases (2) To know how bank secrecy principle can solve money laundering cases. This research is normative research. The result of this research is bank secrecy principle has a link with money laundering cases, so the banking sector is the safe place to save money from money laundering cases. Bank Secrecy Principle is a barrier in law enforcement, Law enforcer should be admired Bank Secrecy Principle because Bank Secrecy Principle is an essential thing in Banking Sector as a trusted sector.
\end{abstract}

Keywords : Bank Secrecy Principle, Money Laundring

\begin{abstract}
Abstrak
Tujuan Penelitian ini, yaitu : (1) Untuk mengetahui hubungan antara adanya prinsip kerahasiaan bank dan munculnya kasus tindak pidana pencucian uang, (2) Untuk mengetahui bagaimana pengaruh prinsip kerahasiaan bank dalam penyelesaian suatu kasus tindak pidana pencucian uang. Penelitian ini merupakan penelitian normatif. Hasil Penelitian menunjukkan bahwa prinsip kerahasiaan bank memiliki hubungan dengan munculnya suatu kasus pencucian uang. Diketahui bahwa dengan adanya prinsip kerahasiaan bank, maka sistem perbankan dianggap sebagai tempat teraman untuk menempatkan uang hasil tindak pidana tersebut. Selain itu Prinsip kerahasiaan bank merupakan penghambat dalam proses penegakkan hukum, penegak hukum juga harus tetap menghormati prinsip tersebut. Hal itu dikarenakan prinsip kerahasiaan bank merupakan hal yang sangat penting dalam suatu sistem perbankan, mengingat sistem perbankan didasarkan pada kepercayaan masyarakat
\end{abstract}

Kata Kunci : Rahasia Bank, Pencucian Uang

\section{PENDAHULUAN}

Modus operandi pencucian uang dari waktu ke waktu terus berubah dan prakteknya semakin kompleks dengan menggunakan teknologi dan rekayasa keuangan yang cukup rumit. Hal itu terjadi baik dalam tahap Placement, layering maupun integration, sehingga penanganannya pun semakin sulit dan membutuhkan peningkatan kemampuan dari aparat penegak hukum 
Pencucian uang erat kaitannya dengan keberadaan bank. Adapun hal-hal yang membuat pelaku tindak pidana tertarik untuk melakukan pencucian uang pada bank yaitu, pertama karena bank menawarkan jasa instrumen dalam lalu lintas keuangan secara cepat, aman, mudah, dan lintas batas negara, karena melibatkan teknologi komunikasi dan informasi yang semakin canggih. Kedua, Adanya pemberian berupa insentif berupa bunga simpanan yang relatif tinggi, sehingga dianggap sangat menguntungkan nasabah. Ketiga, adanya penghargaan, dan penerapan prinsip-prinsip kerahasiaan bank secara ketat.

Prinsip kerahasian pada bank merupakan prinsip yang sangat penting, hal ini disebabkan karena perkembangan dan pertumbuhan suatu bank sangat bergantung pada kepercayaan dari masyarakat. Oleh karena itu, cara bank untuk tetap mempertahankan kepercayaan masyarakat yang menjadi nasabahnya adalah dengan menyimpan rahasia mengenai identitas dan segala yang berkaitan dengan nasabahnya.

Namun, bukan berarti dengan adanya prinsip rahasia bank, tidak memberi dampak negatif terhadap penegakan hukum, terutama berkaitan dengan tindak pidana pencucian uang. Hal tersebut disebabkan karena bank adalah tempat teraman untuk menyimpan uang. Oleh karena itu, penulis tertarik untuk membahas mengenai hubungan antara adanya prinsip kerahasiaan bank terhadap munculnya suatu kasus tindak pidana pencucian uang, dan membahas mengenai pengaruh prinsip kerahasiaan bank dalam penyelesaian suatu kasus tindak pidana pencucian uang. Dalam tulisan ini akan membahas tentang Hubungan antara Adanya Prinsip Kerahasiaan Bank dan Munculnya Kasus Tindak Pidana Pencucian Uang dan bagaimana Pengaruh Prinsip Kerahasiaan Bank dalam Penyelesaian Suatu Kasus Tindak Pidana Pencucian Uang

\section{METODE PENELITIAN}

\section{Jenis Penelitian}

Jenis penelitian yang digunakan adalah penelitian normatif yaitu penelitian hukum kepustakaan yag dapat dilakukan dengan cara meneliti bahan pustaka yang merupakan data sekunder. 


\section{Sumber data}

Sumber data yang digunakan dalam penelitian hukum normatif adalah data sekunder. Data sekunder yang digunakan dalam penelitian ini sebagai berikut :

a. Bahan hukum primer yaitu bahan hukum yang bersifat autoratif terdiri dari peraturan perundang-undangan berkaitan dengan masalah yang diteliti yaitu :

1. Undang-Undang Dasar Republik Indonesia Tahun 1945

2. Undang-Undang Nomor 10 Tahun 1998 Tentang Perbubahan atas Undang-Undang Nomor 7 Tahun 1992

b. Bahan Hukum Sekunder yaitu buku-buku yang berhubungan dengan Hukum Perbankan, Tindak Pidana Pencucian Uang

c. Bahan Hukum Tersier, Kamus-Kamus Besar Bahasa Indonesia

\section{Cara Pengumpulan Data}

Pengumpulan data yang dilakukan dalam penelitian ini adalah melalui kegiatan studi pustaka. Pustaka dimaksud yang berasal dari perundang-undangan dan literatur bidang hukum yang terkait dengan penelitian ini.

\section{Analisis Data}

Metode analisis data yang digunakan adalah analisis kualitatif yaitu analisis yang dilakukan dengan cara mengumpulkan semua data yang telah diperoleh,selanjutnya memisahkan data yang berubungan dengan penelitian. Semua data yang diperoleh kemudian di deskripsikan sehingga mendapatkan langkah untuk melakukan analisis data sehingga mendapat suatu kesimpulan.

\section{HUBUNGAN ANTARA PRINSIP KERAHASIAAN BANK DAN TINDAK PIDANA PENCUCIAN UANG}

Kehidupan bank sangat bergantung kepada kepercayaan masyarakat. Masyarakat hanya akan menjadi nasabah bank yang bersangkutan apabila dari bank ada jaminan, bahwa terhadap keadaan rekening atas uang yang ada pada bank tersebut dapat dipertahankan kerahasiannya. ${ }^{1}$

\footnotetext{
${ }^{1}$ Moch Anwar, Tindak Pidana di Bidang Perbankan, (Bandung: Alumni, 1986), hlm. 85.
} 
Kerahasiaan informasi yang terlahir dalam kegiatan perbankan, diperlukan baik itu untuk kepentingan bank maupun untuk kepentingan nasabah itu sendiri. Hal tersebut didasarkan atas Asas kerahasiaan. Asas kerahasiaan adalah asas yang mengharuskan atau mewajibkan bank sebagai lembaga keuangan untuk merahasiakan segala sesuatu yang berhubungan dengan keuangan dan lain-lain dari nasabah yang menurut kelaziman dunia perbankan, wajib dirahasiakan. ${ }^{2}$ Ketentuan tersebut menegaskan bahwa lembaga perbankan harus memegang teguh keterangan yang tercatat olehnya, ketentuan ini juga berlaku bagi pihak terafiliasi dalam kegiatan operasional perbankan. ${ }^{3}$

Rahasia bank merupakan hal yang sangat penting bagi institusi perbankan itu sendiri, dan secara umum telah diakui sebagai sesuatu hal yang lazimberlaku dan dijaga demi kepentingan nasabah bank.Jika rahasia bank diterobos, tentunyaterkait erat dengan masalah kepercayaan terhadap institusi perbankan, mengingat faktor kepercayaan nasabah bank adalah faktor yang menentukan sekali.

Y. Sri Susilo, Sigit Triandaru, dan A. Totok Budi Santoso, mengemukakan bahwa:

"Salah satu faktor yang dapat mempengaruhi kadar kepercayaan masyarakat kepada bank adalah terjamin atau tidaknya rahasia nasabah yang ada di bank. Data nasabah yang berada di bank,baik data keuangan maupun non-keuangan, seringkali merupakan suatu data yang tidak ingin diketahui oleh orang atau pihak lain. Jumlah kekayaan seseorang yang disimpan di bank bagi nasabah tertentu merupakan sesuatu yang perlu dirahasiakan dari orang lain". 4

Pada dasarnya setiap orang, baik sebagai pribadi maupun sebagai pengusaha, tidak menginginkan keadaan mengenai pribadinya termasuk keadaan keuangannya diketahui oleh orang lain. Tiap-tiap kepentingan dari setiap orang itu harus mendapat perhatian dan dihormati sepenuhnya oleh siapapun juga termasuk negara. Oleh karena itu,maka hal tersebut perlu dilindungi dengan mempergunakan hukum pidana yaitu sejauh kepentingan itu secara langsung maupun tidak langsung.

\footnotetext{
${ }^{2}$ Chainur Arrasjid, Dasar-Dasar Ilmu Hukum, (Jakarta: Sinar Grafika, 2000) hlm. 37.

${ }^{3}$ Muhamad Djumhana, Asas-Asas Hukum Perbankan Indonesia, (Bandung: PT.Citra Aditya Bakti, 2008), hlm. 27.

${ }^{4}$ Y. Sri Susilo, Sigit Triandaru, dan A.Totok Budi Santoso, Bank dan Lembaga Keuangan Lainnya, (Jakarta: Salemba Empat, 2000), hlm. 35.
} 
Bagi seorang pengusaha, kerahasiaan tersebut sangatlah penting artinya demi menunjang kelancaraan perusahannya, karena tanpa hal tersebut setiap orang atau pengusaha lainakan dengan mudah mempelajari keuangan perusahaannya yang kemudian bisadipergunakan untuk mempersulit atau menjatuhkan usahanya. Keadaan seperti itu benar-benar disadari oleh dunia perbankan sehingga bank merasa perlu untuk merahasiakan keadaan keuangan nasabah yang dipercayakan kepadanya. Tindakan tersebut dalam dunia perbankan dikenal dengan Rahasia Bank. ${ }^{5}$

Rahasia bank adalah segala sesuatu yang berhubungan dengan keuangan dan halhal lain dari nasabah bank yang menurut kelaziman dunia perbankan tidak boleh secara terbuka diungkapkan kepada pihak masyarakat. Dalam hubungan ini yang menurut kelaziman wajib dirahasiakan oleh bank, adalah seluruh data dan informasi mengenai segala sesuatu yang berhubungnan dengan keuangan, dan hal-hal lain dari orang, dan badan yang diketahui oleh bank karena kegiatan usahanya.

Istilah rahasia bank mengacu kepada rahasia dalam hubungan antara bank dengan nasabahnya. Akan tetapi, rahasia-rahasia lain yang bukan merupakan rahasia antara bank dengan nasabah, namun juga bersifat "rahasia”, tidak tergolong ke dalam istilah "rahasia bank"menurut Undang-Undang Perbankan. Rahasia-rahasia lain yang bukan rahasia bank tersebut, misalnya rahasia mengenai data dalam hubungan dengan pengawasan bank oleh Bank Indonesia, sebagaimana dimaksud dalam pasal 30 ayat (3) dan pasal 33 Undang-Undang perbankan. ${ }^{6}$

Berdasarkan ketentuan dalam Undang-Undang Nomor 10 Tahun 1998 tentang Perubahan Atas Undang-Undang Nomor 7 Tahun 1992 tentang Perbankan, dikatakan dalam bagian Pasal 1 angka 28 yang menjelaskan mengenai rahasia bank, menerangkan bahwa rahasia bank adalah segala sesuatu yang berhubungan dengan keterangan mengenai nasabah penyimpanan dan simpanannya.

\footnotetext{
${ }^{5}$ Muhamad Djumhana, Rahasia Bank (Ketentuan dan Penerapannya di Indonesia), (Bandung: PT Citra Aditya Bakti, 1966), hlm.129.

${ }^{6}$ Munir Fuady, Hukum Perbankan Modern, (Bandung: PT Citra Adiyta Bakti, 2001), hlm.87.
} 
Kerahasiaan informasi yang terlahir dalamkegiatan perbankan ini diperlukan baik untuk kepentingan bank maupun untuk kepentingan nasabah itu sendiri. Oleh karenanya lembaga perbankan harus memegang teguh keterangan yang tercatat padanya. ${ }^{7}$

Dari rumusan Pasal 40 Undang-Undang No. 10 Tahun 1998, secara eksplisit disebutkan bahwa lingkup rahasia bank adalah menyangkut bukan saja simpanan nasabah tetapi juga identitas nasabah penyimpan yang memiliki simpanan itu. Bahkan dalam rumusan Pasal 40 itu, Nasabah Penyimpan disebut lebih dahulu daripada kata "simpanannya". Dari hal tersebut dapat disimpukan bahwa dalam pikiran pembuat undang-undang, identitas nasabah penyimpannya lebih penting daripada simpanannya, atau untuk menekankan bahwa merahasiakan identitas nasabah penyimpannya sama pentingnya dengan merahasiakan simpanannya. ${ }^{8}$

Ketentuan Rahasia bank tersebut ditujukan untuk kepentingan nasabah agar kerahasiaannya terlindungi. Kerahasiaan tersebut menyangkut keadaan keuangannya. Selain itu, rahasia bank diperuntukkan juga bagi kepentingan bank, agar dapat dipercaya dan menjaga kelangsungan hidupnya terjaga. Di Indonesia, pengaturan rahasia bank lebih dititikberatkan pada alasan untuk kepentingan bank, sebagaimana jelas diatur di dalam Pasal 40 UU Perbankan yang menegaskan bahwa kerahasiaan ini diperlukan untuk kepentingan bank itu sendiri yang memerlukan kepercayaan masyarakat yang menyimpan uangnya di bank.

Ada 5 alasan yang mendasari kewajiban bank untuk merahasiakan segala sesuatu tentang nasabah dan simpanannya, antara lain:

1. Personal privacy;

2. Hak yang timbul dari hubungan perikatan antara bank dan nasabah;

3. Peraturan perundang-undangan yang berlaku;

4. Kebiasaan atau kelaziman dalam dunia perbankan;

\footnotetext{
${ }^{7}$ Asikin, Zainal, Pokok-Pokok Hukum Perbankan di Indonesia, (Jakarta: PT Raja Grafindo Persada, 1995), hlm.53.

${ }^{8}$ Eddy RIfai, Pembukaan Rahasia Bank Untuk Kepentingan Peradilan dalam Perkara Pidana, (Lampung: Universitas Lampung), hlm.7. Diakses dari staff.unila.ac.id, Pada Tanggal 25 November 2015.
} 
5. Karakteristik kegiatan usaha bank sebagai suatu "lembaga kepercayaan" yang harus memegang teguh kepercayaan nasabah yang menyimpan uangnya di bank. ${ }^{9}$

Dibeberapa negara, lingkup dari rahasia bank tidak ditentukan hanya terbatas kepada keadaan keuangan nasabah saja, tetapi meliputi pula identitas nasabah yang bersangkutan. Kemudian perkembangan kemajuan ilmu pengetahuan dan teknologi khususnya dibidang komunikasi telah menyebabkan terintegrasinya sistem keuangan termasuk sistem perbankan yang menawarkan mekanisme lalu lintas antar negara yang dapat dilakukan dalam waktu yang sangat singkat.

Keadaan tersebut selain mempunyai dampak positif, tentunya juga membawa dampak negatif bagi kehidupan masyarakat. Dampak negatif dari hal tersebut yaitu semakin meningkatnya tindak pidana berskala nasional maupun internasioanal dengan memanfaatkan sistem keuangan, termasuk sistem perbankan untuk menyembunyikan atau mengaburkan asal-usul dana hasil tindak pidana (money laundry). ${ }^{10}$

Sistem kerahasiaan bank yang dianut suatu negara, malah menjadi salah satu faktor untuk melakukan pencucian uang. Semakin ketat sistem kerahasiaan perbankan suatu negara maka semakin sering dipergunakan sebagai sarana melakukan pencucian uang. Swiss dan Austria tergolong sebagai Negara yang menerapkan ketentuan perbankan secara ketat.Tidak heran penyimpanan dari banyak negara termasuk negarawan korup,menggunakan jasa bank dari kedua negara tersebut sebagai tempat persembunyian uang kotornya. ${ }^{11}$

Menurut penulis, ketatnya aturan kerahasian mengenai nasabah dan simpanannya, akan memancing orang yang berniat buruk untuk menggunakan aturan mengenai rahasia bank, demi memperoleh keuntungan. Misalnya untuk menyembunyikan uang atau harta kekayaan yang asal usulnya berasal dari hal yang dilarang oleh Undangundang atau dari suatu tindak pidana, karena berpikir bahwa prinsip kerahasiaan bank

\footnotetext{
${ }^{9}$ Yunus Husein, Rahasia Bank: Privasi Versus Kepentingan Umum, (Jakarta : Pascasarjana Fakultas Hukum Universitas Indonesia,2003), hlm.139.

${ }^{10}$ Eka Winarni, Studi Komparasi Hukum Pengaturan Konsep Pembukaan Rahasia Bank Dalam Penyidikan Perkara Money Laundering Antara Indonesia Dan Singapura, (Surakarta: Universitas Sebelas Maret, 2010), hlm. 45.

${ }^{11}$ Adrian Sutedi, Tindak Pidana Pencucian Uang, (Bandung: PT.Citra Aditya Bakti, 2008), hlm.212.
} 
ini akan membantunya menyimpan dan untuk menyamarkan asal usul harta kekayaannya.

Uang atau harta kekayaan yang diperoleh dari berbagai tindak pidana tersebut pada umumnya tidak langsung digunakan atau dibelanjakan oleh pelaku, karena apabila langsung digunakan, tentunya sumber dari harta kekayaan tersebut akan mudah dideteksi oleh aparat penegak hukum.

Pelaku kejahatan akan mengusahakan agar harta kekayaan tersebut terlebih dahulu masuk ke dalam suatu sistim keuangan (financial system) yang sah, dengan tujuan agar harta yang dihasilkan dari tindak pidana tersebut tidak dapat atau sulit untuk dilacak oleh aparat penegak hukum. Harta kekayaan bagi organisasi kejahatan,ibarat bahan bakar bagi sebuah kendaraan. Apabila aliran bahan bakar diputus, maka organisasi kejahatan akan semakin lemah dan kemudian tentunya akan berhenti dan tidak berkegiatan. $^{12}$

Harta kekayaan merupakan hal yang penting dan vital, baik bagi perseorangan maupun organisasi dalam menjalankan kegiatan atau aktivitasnya. Oleh karena itu, usaha untuk menyembunyikan, mengaburkan atau menyamarkan asal usul harta kekayaan yang diperoleh secara tidak sah, haruslah dilakukan sedemikian rupa dan merupakan suatu langkah yang harus dilakukan oleh pelaku. Hal tersebut dilakukan agar terbentuk atau kelihatan adanya jarak atau dinding pemisah antara harta kekayaan dengan tindak pidana yang menghasilkan harta kekayaan tersebut, maka dengan demikian pelaku dapat dengan bebas atau leluasa untuk menikmati atau menggunakan harta tersebut.

Adapun hal-hal yang membuat pelaku tindak pidana tertarik untuk melakukan pencucian uang pada bank adalah sebagai berikut: ${ }^{13}$

1. Bank menawarkan jasa instrumen dalam lalu lintas keuangan secara cepat, aman, mudah, dan lintas batas negara, karena melibatkan teknologikomunikasi dan informasi yang semakin canggih;

${ }^{12}$ I. Tajudin, Analisis Yuridis terhadap Pembukaan Rahasia Bank (Lifting Bank Secrecy) Dikaitkan dengan Undang-Undang 15 Tahun 2002 Tentang Tindak Pidana Pencucian Uang (Money Laundering) Sebagaimana Telah Diubah Dengan Undang-Undang Nomor 25 Tahun 2003, (Bandung: Universitas Padjajaran, 2009), hlm. 15.

${ }^{13}$ Jenriswandi Damanik, Tindak Pidana Pencucian Uang dan Penegakan Hukumnya, (Medan: Universitas Simalungun, 2014), hlm.7. Diakses dari USI.ac.id, Pada Tanggal 25 November 2015. 
2. Adanya pemberian berupa insentif berupa bunga simpanan yang relative tinggi, sehingga dianggap sangat menguntungkan nasabah;

3. Adanya penghargaan, dan penerapan prinsip-prinsip kerahasiaan bank secara ketat.

Ketertarikan pelaku untuk melakukan pencucian uang dalam sistem ini disebabkan adanya keunggulan-keunggulan dari sistem perbankan. Keunggulan itu antara lain, pertama, bank menawarkan jasa instrumen dalam lalu lintas keuangan secara cepat, aman, mudah dan lintas batas negara (transnational) karena melibatkan teknologi komunikasi dan informasi yang semakin canggih. Kedua, pemberian insentif berupa bunga simpanan yang relatif tinggi sehingga sangat menguntungkan penyimpan. Ketiga, penghargaan dan penerapan prinsip-prinsip kerahasiaan bank (bank secrecy principle) secara ketat. ${ }^{14}$

Dalam konteks penegakan hukum, istilah money laundering bukanlah suatu konsep yang sederhana, melainkan sangat rumit karena masalahnya demikian kompleks, sehingga cukup sulit untuk merumuskan delik-delik hukumnya secara objektif dan efektif. Bagi pelaku kejahatan pencucian uang, bahwa menyimpan uang dalam jumlah besar di bank, adalah perbuatan yang wajar, karena semuanya dilakukan dengan melalui prosedur sebagaimana yang telah ditetapkan oleh perbankan. Jika dilihat dari sisi ketentuan hukum, bahwa perbuatan menyimpan uang di bank tidak lagi dapat dilihat dari segi hubungan keperdataan sebagaimana lazimnya dalam dunia perbankan. Hal tersebut disebabkan karena si penyimpan dana, berusaha untuk mengaburkan atau menyamarkan asal usul uang yang disimpannya, karenanya perbuatan itu merupakan suau kejahatan yang perlu ditindak dan diberantas. ${ }^{15}$

Secara umum, money laundering merupakan metode untuk menyembunyikan, memindahkan, dan menggunakan hasil dari suatu tindak pidana, kegiatan organisasi tindak pidana, tindak pidana ekonomi, korupsi, perdagangan narkotika dan kegiatankegiatan lainnya yang merupakan aktivitas tindak pidana.

${ }^{14}$ Eka Winarni, Studi Komparasi Hukum Pengaturan Konsep Pembukaan Rahasia Bank Dalam Penyidikan Perkara Money Laundering Antara Indonesia Dan Singapura, (Surakarta: Universitas Sebelas Maret, 2010), hlm.50.

${ }_{15}$ M. Arief Amrullah, Tindak Pidana Pencucian Uang Money Loundering, (Malang: Bayu Media Publishing, 2004), hlm.1 - 3. 
Melihat pada definisi di atas, maka money laundering atau pencucian uang pada intinya melibatkan aset yaitu pendapatan atau kekayaan yang disamarkan atau disembunyikan asal-usulnya sehingga dapat digunakan tanpa terdeteksi bahwa aset tersebut berasal dari kegiatan yang ilegal. Melalui money laundering,pendapatan atau kekayaan yang berasal dari kegiatan yang melawan hukum diubah menjad iaset keuangan yang seolah-olah berasal dari sumber yang sah atau legal.

Kegiatan pencucian uang merupakan konsekuensi yang hampir pasti terjadi pada semua perolehan keuntungan yang berpotensi membangkitkan unsur-unsur kejahatan. Pada umumnya pelaku cenderung untuk mencari daerah yang memiliki risiko rendah atau lemah atau tidak efektif dalam mendeteksi kegiatan pencucian uang. Karena tujuan pencucian uang adalah untuk mendapatkan dana tersebut kembali kepada orang-orang yang me-generatenya, pelaku umumnya lebih memilih untuk memindahkan dananya ke daerah-daerah yang financial system-nya telah established. ${ }^{16}$

Perbedaan antara sistem anti money laundering di suatu negara akan dapat dieksploitasi oleh pelaku, yang cenderung untuk memindahkan jaringan mereka ke negara-negara dan sistem keuangan yang lemah atau yang memiliki tindakan pencegahan yang tidak efektif (ineffective countermeasures).Teknik pencucian uang yang seringkali dilakukan adalah melalui industri perbankan. Hal ini disebabkan karena bank banyak menawarkan jasa dalam lalu lintas keuangan yang dapat dimanfaatkan oleh pelaku, untuk menyembunyikan atau menyamarkan asal usul dana. ${ }^{17}$

Kegiatan pencucian uang melibatkan aktivitas yang sangat kompleks. Pada dasarnya kegiatan tersebut terdiri dari tiga langkah yang masing-masing berdiri sendiri tetapi seringkali dilakukan bersama-sama yaitu placement, layering dan integration: ${ }^{18}$

1) Placement diartikan sebagai upaya untuk menempatkan dana yang dihasilkan dari suatu aktivitas kejahatan. Dalam hal ini terdapat pergerakan fisik dari uang

\footnotetext{
${ }^{16}$ Ari Purwadi, Jasa Private Banking Pada Lembaga Perbankan Sebagai Sasaran Dan Sarana Pencucian Uang, (Surabaya: Universitas Wijaya Kusuma, 2012), hlm. 15. Diakses dari ejurnal.uwks.ac.id, Pada Tanggal 25 November 2015. 2005), hlm.16.

${ }^{17}$ NHT. Siahaan, Pencucian Uang dan Kejahatan Perbankan, (Jakarta: Pustaka Sinar Harapan,

${ }^{18}$ Yunus Husein, Kebijakan Bank Indonesia tentang Money Laundering, Disampaikan dalam rangka Seminar Undang-Undang Nomor 15 Tahun 2002 Tentang Tindak Pidana Pencucian Uang, diselenggarakan oleh Lembaga Info Naker, (Jakarta, 27 Juni 2002), hlm.2. Diakses dari https://yunushusein.files.wordpress.com, Pada tanggal 25 November 2015.
} 
tunai baik melalui penyelundupan uang tunai dari satu negara ke negara lain, menggabungkan antara uang tunai yang berasal dari kejahatan dengan uang yang diperoleh dari hasil kegiatan yang sah, ataupun dengan melakukan penempatan uang giral ke dalam sistem perbankan misalnya deposito bank, cek atau melalui rela estate atau saham-saham atau juga mengkonversikan ke dalam mata uang lainnya atau transfer uang ke dalam valuta asing.

2) Layering diartikan sebagai memisahkan hasil kejahatan dari sumbernya yaitu aktivitas kejahatan yang terkait melalui beberapa tahapan transaksi keuangan. Dalam hal ini terdapat proses pemindahan dana dari beberapa rekening atau lokasi tertentu sebagai hasil placement ke tempat lainnya melalui serangkaian transaksi yang kompleks yang didesain untuk menyamarkan/mengelabui sumber dana "haram" tersebut. Layering dapat pula dilakukan melalui pembukaan sebanyak mungkin rekening perusahaan-perusahaan fiktif dengan memanfaatkan ketentuan rahasia bank.

3) Integration yaitu upaya untuk menetapkan suatu landasan sebagai suatu 'legitimate explanation' bagi hasil kejahatan. Disini uang yang di'cuci' melalui placement maupun layering dialihkan ke dalam kegiatan-kegiatan resmi sehingga tampak tidak berhubungan sama sekali dengan aktivitas kejahatan sebelumnya yang menjadi sumber dari uang yang di-Iaundry. Pada tahap ini uang yang telah di-Iaundry dimasukan kembali ke dalam sirkulasi dengan bentuk yang sejalan dengan aturan hukum.

Praktek money loundering tidak mudah untuk memberantasnya. Ada beberapa faktor yang menjadi penyebabnya. Faktor-faktor tersebut sekaligus merupakan pendorong maraknya praktek money loundering diantaranya sebagai berikut:

a) Ketentuan rahasia bank yang sangat ketat dari negara yang bersangkutan.

b) Dimungkinkan oleh ketentuan perbankan di negara tersebut seseorang menyimpan dana disuatu bank dilakukan dengan menggunakan nama samaran atau tanpa nama.

c) Pemerintah yang bersangkutan memang dengan sengaja membiarkan praktek money loundering itu berlangsung dinegara tersebut, karena negara yang 
bersangkutan memperoleh keuntungan dari dilakukannya penempatan uang haram itu diperbankan negara tersebut.

Kemudian, di Indonesia khusunya, terdapat kondisi-kondisi yang membuat marak terjadinya tindak pidana tersebut. Kondisi diIndonesia yang mendukung terjadinya tindak pidana pencucian uang (money laundering) yaitu sebagai berikut: ${ }^{19}$

1) Ketatnya ketentuan mengenai rahasia bank, sehingga tidak mungkin sembarang orang untuk mengetahui asal-usul uang tersebut sehingga amanlah uang tersebut dibersihkan oleh lembaga keuangan tersebut.

2) Sistem devisa bebas, sehingga otoritas moneter sulit untuk mendeteksi lalu lintas modal, dana dan uang dari manapun datangnya.

3) Tidak adanya ketentuan pembatasan atau larangan kepada orang asing yang masuk ke wilayah Indonesia dalam hal membawa valuta asing juga tidak adanya kewajiban pelaporannya, sehingga orang bebas membawa uangke luar masuk berapapun besarnya.

4) Kebebasan yang diberikan Pemerintah dalam hal perpajakan yang menyangkut deposita dan simpanan, yaitu asal-usul uang tersebut tidak dapat diusut.

5) Dan ketentuan lainnya.

Sistem kerahasiaan bank dan kelemahan perangkat hukum di Indonesia juga merupakan sarana yang dimanfaatkan oleh para pelaku pencucian uang. Adanya pengaturan kerahasiaan ini membuat mereka merasa aman untuk menyimpan uang hasil kejahatannya tanpa harus takut akan dilacak oleh pihak berwenang. Selain itu kondisi yang mengakibatkan negara ini menjadi "surga" kegiatan pencucian uang adalah karena Indonesia masih membutuhkan likuiditas, sehingga dunia perbankan Indonesia masih memandang pentingnya dana-dana asing untuk masuk dan diinvestasikan di Indonesia. Sementara ada pihak-pihak asing tertentu yang hanya setuju untuk melakukan investasi di Indonesiajika dijamin tidak diusut asal-usul dananya. ${ }^{20}$

${ }^{19}$ Muhamad Djumhana, Hukum Perbankan Indonesia, (Bandung: PT. Citra Aditya Bakti, 2006), hlm. 601 .

20 Benny Swastika, Tinjauan Hukum Asas Pembuktian Terbalik dalam TIndak PIdana Pencucia Uang, (Jakarta: Universitas Indonesia, 2011), hlm.28. 


\section{PENGARUH PRINSIP KERAHASIAAN BANK DALAM PENYELEASIAN KASUS TINDAK PIDANA PENCUCIAN UANG}

Konsep rahasia bank timbul dari tujuan untuk melindungi nasabah bank yang bersangkutan. Hal tersebut nyata terlihat ketika Court of Appeal Inggris secara bulat memutuskan pendiriannya dalam kasus Tournier v. National Provincial and Union Bank of England tahun 1924. Putusan pengadilan tersebut kemudian menjadi leading case law yang menyangkut ketentuan rahasia bank di Inggris dan kemudian dijadikan acuan oleh pengadilan-pengadilan di negara-negara lain yang menganut common law system. Bahkan 60 tahun sebelum putusan Tournier tersebut, yaitu dalam perkara Foster v. The Bank of London tahun 1862, juri telah berpendapat bahwa terdapat kewajiban bagi bank untuk tidak boleh mengungkapkan keadaan keuangan nasabah bank yang bersangkutan kepada pihak lain. Namun pada waktu itu pendirian tersebut belum memperoleh afirmasi dari putusan-putusan pengadilan berikutnya. ${ }^{21}$

Timbulnya pemikiran untuk perlunya merahasiakan keadaan keuangan nasabah bank, membuat timbulnya suatu ketentuan hukum mengenai kewajiban rahasia bank. Rahasia bank bertujuan untuk melindungi kepentingan nasabah secara individual. Ketentuan rahasia bank di Swiss, yaitu suatu negara yang dikenal mempunyai ketentuan rahasia bank yang dahulunya paling ketat di dunia, awalnya juga bertujuan untuk melindungi kepentingan nasabah bank secara individual. Ketentuan rahasia bank di Swiss lahir sehubungan dengan kedudukan Swiss sebagai negara yang netral secara tradisional

Ada beberapa alasan yang membuat Swiss memiliki ketentuan rahasia bank yang ketat. Alasan pertama, yaitu pada abad ke-17, ribuan kaum Huguenots dari Perancis melarikan diri ke Swiss oleh karena mereka dikejar-kejar atau dilakukan penyiksaanpenyiksaan terhadap mereka sehubungan dengan agama yang mereka anut. Diantara mereka itu kemudian ada yang menjadi bankir, dan menginginkan agar supaya kerahasiaan dari nasabah-nasabah mereka untuk urusan-urusan keuangannya di negara

\footnotetext{
${ }^{21}$ Dennis Campbell dalam Adrian Sutedi, Hukum Perbankan Suatu Tinjauan Pencucian Uang, Merger, Likuidasi, dan Kepailitan, (Jakarta: Sinar Grafika, 2010), hlm. 1.
} 
asalnya dirahasiakan. Alasan kedua adalah sehubungan dengan dikejar-kejarnya orangorang Yahudi di waktu regime Nazi berkuasa di Jerman di tahun 1930an dan 1940an. ${ }^{22}$

Dari uraian tersebut, diketahui bahwa sejak waktu itu, ketentuan rahasia bank bersifat mutlak, artinya tidak dapat dikecualikan karena alasan apapun juga.Namun perkembangan sehubungan dengan keadaan politik dalam negeri, keadaan sosial, terutama yang menyangkut timbulnya kejahatan-kejahatan di bidang money laundering, dan kebutuhan akan adanya stabilitas ekonomi, terutama stabilitas moneter, telah menimbulkan kebutuhan akan perlunya pelonggaran terhadap kewajiban rahasia bank yang mutlak itu. Artinya, apabila kepentingan negara, bangsa dan masyarakat umum harus didahulukan daripada kepentingan nasabah secara pribadi, maka kewajiban bank untuk melindungi kepentingan nasabah secara individual, harus dapat dikesampingkan. Contoh konkrit mengenai hal tersebut adalah berkaitan dengan kepentingan negara untuk menghitung memungut, pajak nasabah yang bersangkutan, penindakan korupsi, dan pemberantasan money laundering. ${ }^{23}$

Pelanggaran rahasia bank yang diatur oleh masing-masing negara dapat dikelompokkan dalam dua kelompok, yaitu sebagai berikut:

1. Kelompok pertama, yaitu kelompok yng menentukan bahwa pelanggaran rahasia bank adalah pelanggaran perdata (civil violation). Negara-negara tersebut membiarkan kewajiban bank hanya sebagai kewajiban yang timbul dari hubungan kontraktual belaka antara bank dan nasabah, namun kewajiban kontraktual tersebut dapat disimpangi apabila kepentingan umum menghendaki dan apabila secara tegas dikecualikan oleh ketentuan Undangundang tertentu. Hal yang demikian misalnya dapat terlihat pada ketentuan rahasia bank menurut hukum Inggris, Amerika Serikat, Kanada, Australia, Negeri Belanda, Belgia, The Bahamas, The Cayman Islands dan beberapa negara lainnya.

2. Kelompok yang kedua menentukan pelanggaran rahasia bank sebagai pelanggaran pidana (criminal violation), misalnya Swiss, Austria, Korea

${ }^{22}$ Dennis Campbell dalam Adrian Sutedi, Ibid, hlm.2.

23 Sutan Remy Sjahdeini, Rahasia Bank: Berbagai Masalah Disekitarnya, Makalah ini disajikan sebagai bahan diskusi mengenai legal isues seputar Pengaturan Rahasia Bank, (Jakarta: Bank Indonesia, Senin 13 Juni 2005), hlm.3. Diakses dari www.oocities.org, Pada tanggal 25 November 2015. 
Selatan, Perancis, Luxembourg, dan Indonesia, serta beberapa negara lainnya. $^{24}$

Di Indonesia, diketahui dari penjelasan Pasal 40 ayat (1) Undang-Undang No. 7 Tahun 1992 bahwa kerahasiaan itu diperlukan untuk kepentingan bank, dimana bank memerlukan kepercayaan dari masyarakat yang menyimpan uang.Oleh karena itu,dapat disimpulkan bahwa lingkup rahasia bank memang menyangkut simpanan nasabah.

Ketentuan rahasia bank menurut Undang-Undang No. 7 Tahun 1992 berlaku bukan saja menyangkut keadaan keuangan dari nasabah penyimpan dana (pasiva bank), tetapi berlaku pula bagi kredit yang diperoleh oleh nasabah debitur dari bank tersebut (aktiva bank). Hal tersebut dapat juga disimpulkan dari penjelasan Pasal 44 ayat (1) dan ayat (2) yang berkaitan dengan informasi antara bank mengenai kredit. ${ }^{25}$

Sementara itu, Undang-undang No. 10 Tahun 1998 memberikan pengecualian dalam tujuh hal. Pengecualian tersebut bersifat limitatif, artinya di luar tujuh hal yang telah dikecualikan itu tidak terdapat pengecualian yang lain. Ketujuh pengecualian itu adalah sebagai berikut:

1. Untuk kepentingan perpajakan dapat diberikan pengecualian kepada pejabat pajak berdasarkan perintah Pimpinan Bank Indonesia atas permintaan Menteri Keuangan (Pasal 41).

2. Untuk penyelesaian piutang bank yang sudah diserahkan kepada Badan Urusan Piutang Dan Lelang Negara/Panitia Urusan Piutang Negara dapat diberikan pengecualian kepada pejabat Badan Urusan Piutang Dan Lelang Negara/Panitia Urusan Piutang Negara atas izin Pimpinan Bank Indonesia (Pasal 41A).

3. Untuk kepentingan peradilan dalam perkara pidana dapat diberikan pengecualian kepada polisi, jaksa atau hakim atas izin Pimpinan Bank Indonesia (Pasal 42).

4. Dalam perkara perdata antara bank dengan nasabahnya dapat diberikan pengecualian tanpa harus memperoleh izin Pimpinan Bank Indonesia (Pasal 43).

\footnotetext{
${ }^{24}$ Francis Neate \& Roger McCormick dalam Adrian Sutedi, Op.Cit.

${ }^{25}$ Sutan Remy Sjahdeini, Ibid, hlm.9.
} 
5. Dalam rangka tukar-menukar informasi di antara bank kepada bank lain dapat diberikan pengecualian tanpa harus memperoleh izin Pimpinan Bank Indonesia (Pasal 44). Termasuk di dalam pengertian tukar menukar informasi antar bank itu adalah dalam penggunaan ATM bersama.

6. Atas persetujuan, permintaan atau kuasa dari Nasabah Penyimpan secara tertulis dapat diberikan pengecualian tanpa harus memperoleh izin Pimpinan Bank Indonesia (Pasal 44A ayat (1)).

7. Ahli waris yang sah dari nasabah penyimpan dalam hal nasabah penyimpan telah meninggal dunia (Pasal 44A ayat (2)).

Seperti yang dikemukakan oleh Leden Marpaung, rahasia bank dapat dibuka bila ditujukan untuk kepentingan penegakan hukum dan keadilan. ${ }^{26}$ Tentunya disesuaikan dengan perintah Undang-undang untuk merahasiakan dan membuka kerahasiaan bank. Penegasan ketentuan tersebut dapat dijumpai di Pasal 40 ayat (1) Undang-Undang Nomor 7 Tahun 1992 bahwa, bank dilarang memberikan keterangan yang tercatat pada bank tentang keadaan keuangan dan hal-hal lain dari nasabahnya, yang wajib dirahasiakan oleh bank menurut kelaziman dunia perbankan, kecuali dalam hal sebagaimana yang dimaksud dalam Pasal 41, Pasal 42, Pasal 43, dan Pasal 44.

Pada rahasia bank, seperti yang diketahui bahwa dari keterangan yang ada di bank dapat diketahui mengenai kegiatan seseorang, dimana saja berada pada waktu tertentu, majalah apa yang dibacanya, pola konsumsinya, organisasi yang dimasukinya atau disumbangnya.Dengan kata lain bahwa dokumen nasabah yang ada di bank merupakan cerminan dari diri nasabah.

Menurut Sutan Remy Sjahdeini bahwa rahasia bank sangat terkait dengan kepercayaan nasabah untuk memelihara dan meningkatkan kepercayaan masyarakat terhadap suatu bank. Dalam hukum positif di Indonesia, pengaturan mengenai rahasia bank terdapat dalam Undang-Undang No.10 tahun 1998 Tentang Perubahan Atas Undang-Undang No.7 Tahun 1992 Tentang Perbankan. ${ }^{27}$ Menurut Pasal 1 Angka 8, Rahasia bank adalah segala sesuatu yang berhubungan dengan keterangan mengenai Nasabah Penyimpan dan Simpanannya.

\footnotetext{
${ }^{26}$ Leden Marpaung, Kejahatan Perbankan, (Jakarta: Erlangga, 1993), hlm.42.

${ }^{27}$ Sutan Remy Sjahdeini, Op.Cit.
} 
Rahasia Bank merupakan hal yang sangat penting dalam suatu sistem perbankan karena berkaitan dengan kepercayaan masyarakat, kepercayaan masyarakat tersebut erat kaitanya dengan pertumbuhan dan perkembangan suatu bank, sehingga bank menjaga dengan erat rahasia nasabahnya. Akan tetapi, seiring berjalannya waktu, adanya prinsip kerahasiaan bank tersebut telah memberikan kesulitan tersendiri dalam penegakan hukum. Seperti yang diketahui bahwa modus dan cara dari suatu tindak pidana juga tentunya mengalami perkembangan, misalnya dengan memanfaatkan informasi dan teknologi.

Tindak Pidana Pencucian Uang merupakan salah satu tindak pidana yang memanfaatkan perkembangan teknologi dari sistem perbankan. Akan tetapi, menjadi terhambat saat akan diselesaikan, karena adanya pengaruh dari prinsip kerahasiaan bank. Adanya prinsip kerahasiaan bankberarti bank tidak bisa begitu saja membuka rahasia mengenai nasabahnya.

Diketahui bahwa kegiatan pencucian uang memiliki akibat negatif yang sangat besar bagi sektor perekonomian dan penegakan hukum. Menurut Pemerintah Kanada dalam sebuah kertas kerja yang dikeluarkan pada Oktober 1998, disebutkan ada beberapa kerugian yang ditimbulkan oleh kegiatan pencucian uang terhadap masyarakat. Kerugian-kerugian tersebut adalah sebagai berikut: (Departement of Justice Canada, Solicitor General Canada, Electronic Money Laundering: An Environmental Scan, October 1998). ${ }^{28}$

1) Pencucian uang memungkinkan penjual dan pengedar narkoba, penyelundup dan para penjahat lainnya untuk dapat memperluas kegiatan operasinya. Hal ini akan meningkatkan biaya penegakan hukum dalam pemberantasannya serta peningkatan biaya perawatan dan pengobatan kesehatan bagi masyarakat pencandu narkoba;

2) Kegiatan pencucian uang berpotensi untuk merongrong keuangan masyarakat (financial community) sebagai akibat dari besarnya uang yang terlibat dalam

${ }^{28}$ Eka Winarni, Studi Komparasi Hukum Pengaturan Konsep Pembukaan Rahasia Bank Dalam Penyidikan Perkara Money Laundering Menurut UU No. 25 Tahun 2003 Tentang Tindak Pidana Pencucian Uang Dengan Republic Of The Philippines Code No.9160 On Anti Money Laundering Act Of 2001, (Surakarta: Universitas Sebelas Maret, 2010), hlm.57. Diakses dari http://core.ac.uk/, Pada Tanggal 25 November 2015. 
kegiatan tersebut. Potensi untuk melakukan korupsi bertambah besar sejalan dengan meningkatnya peredaran uang haram dalam jumlah yang signifikan;

3) Pencucian uang mengurangi pendapatan pemerintah dari sektor pajak dan secara tidak langsung merugikan wajib pajak (masyarakat) yang jujur serta mengurangi kesempatan kerja yang legal.

Kegiatan pencucian uang juga, dapat menyebabkan berkurangnya kepercayaan masyarakat terhadap perbankan, kemudian pada akhirnya akan mengganggu sistem keuangan dan pembayaran nasional dan internasional. Pencucian uang juga dapat mengurangi kepercayaan negara lainterhadap suatu negara, contohnya Indonesia, karena dinilai tidak mampu mengatasi kegiatan pencucian uang. Terakhir, pencucian uang menimbulkan ketidakpastian hukum dan instabilitas keamanan nasional. ${ }^{29}$

Mengingat kerugian yang ditimbulkan oleh kegiatan pencucian uang sangat besar, baik bagi masyarakat, sektor perekonomian dan perbankan, maupun negara, maka kriminalisasi yang kemudian dilanjutkan dengan penegakan hukum tindak pidana pencucian uang dinilai sebagai langkah yang tepat dalam usaha mencegah dan memberantas tindak pidana pencucian uang di Indonesia.

Salah satu faktor penghalang bagi penegak hukum untuk dapat berhasil mengungkapkan tindak pidana pencucian uang adalah ketentuan rahasia bank yang terlalu ketat di negara yang bersangkutan. Menyadari hal yang demikian itu, maka Tim yang merancang Undang-Undang No. 15 Tahun 2002 tentang Tindak Pidana Pencucian Uang sebagaimana kemudian telah diubah dengan Undang-Undang No. 25 Tahun 2003 kemudian telah diubah lagi dengan Undang-undang No. 8 Tahun 2010 tentang Pencegahan dan Pemberantasan Tindak Pidana Pencucian Uang. Undang-undang tersebut telah memberikan pengecualian kepada penyidik, penuntut umun, dan hakim untuk memperoleh keterangan mengenai nasabah penyimpan dan simpanannya dengan cara menyimpang dari ketentuan rahasia bank yang ditentukan dalam Undang-Undang No. 7 Tahun 1992 sebagaimana telah diubah dengan Undang-Undang No. 10 Tahun 1998.

\footnotetext{
${ }^{29}$ Ibid, hlm. 60.
} 
Pencucian uang atau money laundering menurut Black's Law Dictionary, Money Laundering is term used to describe invesement or other transfer of money flowing from racketeering, drug transaction and other illegal sources into legitimate channels so that its originals source can not betraced (Pencucian Uang adalah istilah yang digunakan dalam menjelaskan aktivitas, dalam hal menguraikan atau memindahkan asalusul yang tidak sah menjadi seolah-olah sah, sehingga sumber asalnya tidak dapat diusut ataupun dideteksi). ${ }^{30}$

Kemudian di Indonesia, pada Pasal 3 Undang-undang No. 8 Tahun 2010tentang tindak pidana pencucian uang, dapat diketahui bahwa tindak pidana pencucian uang adalah menempatkan, mentransfer, mengalihkan, membelanjakan, membayarkan, menghibahkan, menitipkan, membawa ke luar negeri, mengubah bentuk, menukarkan dengan mata uang atau surat berharga atau perbuatanlain atas Harta Kekayaan yang diketahuinya atau patut diduganya merupakan hasil tindak pidana sebagaimana dimaksud dalam Pasal 2 ayat (1) dengan tujuan menyembunyikan atau menyamarkan asal usul Harta Kekayaan. Pada pasal 4 undang-undang tersebut, diketahui bahwa pencucian uang juga termasuk kegiatan menyembunyikan atas menyamarkan asal-usul, sumber, lokasi, peruntukan, pengalihan hak-hak, atau kepemilikan yang sebenarnya atas Harta Kekayaan yang diketahuinya atau patut diduganya merupakan hasil tindak pidana sebagaimana dimaksud dalam Pasal 2 ayat (1). ${ }^{31}$

Dari Pasal 2 Undang-undang No. 8 Tahun 2010 tentang Pencegahan dan Pemberantasan Tindak Pidana Pencucian Uang, diketahui bahwa tindak pidana yang berhubungan dengan pencucian uang adalah sebagai berikut:

1. Korupsi, penyuapan, narkotika, psikotropika, penyelundupan tenaga kerja, penyelundupan migran, di bidang perbankan, di bidang pasar modal, di bidang perasuransian, kepabeanan, cukai, perdagangan orang, perdagangan senjata gelap, terorisme, penculikan, pencurian, penggelapan, penipuan, pemalsuan uang, perjudian, prostitusi.

\footnotetext{
${ }^{30}$ Black`s Law Dictionary dalam Anita Tiar Kusuma Wardhani, Studi Perbandingan Tentang Pengaturan Pemberian Perlindungan Saksi Dalam Undang-Undang Tindak Pidana Pencucian Uang Di Negara Indonesia Dan Malaysia, (Surakarta: Universitas Sebelas Maret, 2008), hlm. 51. Diakses dari digilibs.uns.ac.id, Pada Tanggal 25 November 2015.

${ }^{31}$ Indonesia, Pencegahan dan Pemberantasan Tindak Pidana Pencucian Uang, Undamgundang No. 8 Tahun 2010, LN No. 122 Tahun 2010, TLN No. 5164.
} 
2. Tindak pidana di bidang perpajakan, di bidang kehutanan, di bidang lingkungan hidup, di bidang kelautan dan perikanan;

3. Tindak pidana lain yang diancam dengan pidana penjara 4 (empat) tahun atau lebih, yang dilakukan di wilayah Negara Kesatuan Republik Indonesia atau di luar wilayah negara kesatuan republik Indonesia dan tindak pidana tersebut juga merupakan tindak pidana menurut hukum Indonesia.

4. Kemudian termasuk harta kekayaan yang diketahui atau patut diduga akan digunakan dan atau digunakan secara langsung atau tidak langsung untuk kegiatan terorisme, organisasi teroris, atau teroris perseorangan disamakan sebagai hasil tindak pidana

Menurut Pasal 72 ayat (1) Undang-undang Tindak Pidana Pencucian Uang, untuk kepentingan pemeriksaan dalam perkara tindak pidana pencucian uang, penyidik, penuntut umum atau hakim berwenang untuk meminta keterangan dari Penyedia Jasa Keuangan mengenai Harta Kekayaan setiap orang yang telah dilaporkan oleh Pusat Pelaporan dan Analisis Transaksi Keuangan (PPATK), tersangka, atau terdakwa. Pasal 72 ayat (2) Undang-Undang tersebut menentukan bahwa dalam meminta keterangan sebagaimana dimaksud pada ayat (1), terhadap penyidik, penuntut umum atau hakim tidak berlaku ketentuan Undang-Undang yang mengatur tentang rahasia bank dan kerahasiaan transaksi keuangan lainnya.

Kemudian mengenai kemungkinan penerobosan rahasia bank seperti sudah ditegaskan oleh Undang-undang bahwa untuk kepentingan perpajakan, untuk penyelesaian piutang bank yang sudah diserahkan kepada badan urusan piutang lelang negara atau panitia urusan piutang negara, dan untuk kepentingan peradilan diwajibkan bagi pihak tersebut untuk terlebih dahulu memperoleh izin tertulis untuk membuka rahasia bank dari pimpinan bank Indonesia. Hal tersebut ditegaskan oleh Pasal 3 ayat (1) Peraturan Bank Indonesia Nomor: 2/19/PBI /2000 tentang persyaratan dan tata cara pemberian perintah atau izin tertulis membuka rahasia bank bahwa pelaksanaan ketentuan sebagaimana dimaksud dalam Pasal 2 ayat (4) huruf a, b, dan c, wajib terlebih dahulu memperoleh perintah atau izin tertulis untuk membuka rahasia bank dari pimpinan bank Indonesia. 
Prosedur tersebut dijalankan demi menjaga kepercayaan nasabah. Ketika membuka informasi rahasia bank yang dianggap penting, maka diharapkan mencantumkan keterangan-keterangan dan memperlihatkan bukti-bukti tertulis serta surat-surat yang dapat mendukung untuk membuka rahasia bank. Rahasia bank yang dimaksud berupa seluruh informasi mengenai nasabah penyimpan dan simpanannya. ${ }^{32}$

Kemudian agar penggunaan fasilitas pengecualian yang diberikan oleh Undangundang Tindak Pidana Pencucian Uang tidak disalahgunakan, maka Undang-undang Tindak Pidana Pencucian Uang memberikan rambu-rambu bagi penyidik, penuntut umum atau hakim dalam mengajukan permintaan keterangan kepada penyedia jasa keuangan. Hal tersebut sebagaimana yang ditentukan padaPasal 72 ayat (3), bahwa permintaan keterangan harus diajukan secara tertulis dengan menyebutkan secara jelas hal-hal sebagai berikut:

1. Nama dan jabatan penyidik, penuntut umum, atau hakim;

2. Identitas setiap orang yang telah dilaporkan oleh PPATK, tersangka, atau terdakwa;

3. Tindak pidana yang disangkakan atau didakwakan; dan

4. Tempat harta kekayaan berada.

Sementara itu Pasal 72 ayat (5) menentukan bahwa surat permintaan untuk memperoleh keterangan sebagaimana dimaksud pada ayat (1) dan ayat (2) harus ditandatangani oleh:

1. Kepala Kepolisian Negara Republik Indonesia atau Kepala Kepolisian Daerah dalam hal permintaan diajukan oleh penyidik;

2. Jaksa Agung Republik Indonesia atau Kepala Kejaksaan Tinggi dalam hal permintaan diajukan oleh penuntut umum;

3. Hakim Ketua Majelis yang memeriksa perkara yang bersangkutan.

Dari keseluruhan uraian diatas, diketahui bahwa prinsip kerahasiaan bank, menjadi pemicu adanya suatu tindak pidana pencucian uang. Sistem kerahasiaan bank yang dianut suatu negara, menjadi salah satu faktor untuk melakukan pencucian uang.

32 Anak Agung Istri Chandra Pramita Sukawati, Pengaturan Kewajiban Bank Menjaga Kerahasiaan Data Nasabah Penyimpan Menurut Undang-Undang Perbankan, (Bali: Tesis Universitas Udayana, 2015), hlm 59. Diakses dari www.pps.unud.ac.id, Pada tanggal 25 November 2015. 
Semakin ketat sistem kerahasiaan perbankan suatu negara maka semakin sering dipergunakan sebagai sarana melakukan pencucian uang.

Ketentuan rahasia bank yang terlalu ketat di suatu negara merupakan salah satu faktor penghambat bagi penegak hukum, untuk cepat mengungkap suatu tindak pidana pencucian uang. Hal tersebut disebabkan karena bank menolak membuka informasi mengenai nasabahnya.

Di Indonesia, awalnya prinsip kerahasiaan bank merupakan prinsip yang sangat ketat. Akan tetapi, kerahasiaan bank tersebut, sudah dapat dikecualikan terhadap beberapa hal yaitu, untuk kepentingan perpajakan, untuk penyelesaian piutang bank yang sudah diserahkan kepada badan urusan piutang lelang negara atau panitia urusan piutang negara, dan untuk kepentingan peradilan. Hal tersebut sebagaimana yang di amanatkan oleh Undang-undang.

Namun untuk membuka kerahasiaan bank tersebut, pihak- pihak yang berkepentingan itu, harus terlebih dahulu memperoleh izin tertulis untuk membuka rahasia bank dari Pimpinan Bank Indonesia. Prosedur tersebut dijalankan demi menjaga kepercayaan nasabah. Ketika membuka informasi rahasia bank dianggap penting, seyogyanya diharapkan mencantumkan keterangan-keterangan dan memperlihatkan bukti-bukti tertulis serta surat-surat yang dapat mendukung untuk membuka rahasia bank yaitu berupa seluruh informasi mengenai nasabah penyimpan dan simpanannya.

Kemudian mengenai pengecualian terhadap ketentuan rahasia bank dalam rangka pemberantasan dan penindakan tindak pidana pencucian uang di Indonesia, hanya dapat diberikan apabila pemeriksaan tindak pidana pencucian uang telah memasuki tahap penyidikan. Artinya, nasabah penyimpan harus telah menjadi tersangka. Apabila masih dalam tahap penyelidikan, dan nasabah penyimpan belum menjadi tersangka, maka keterangan mengenai nasabah penyimpan dan simpanannya tidak boleh diungkapkan oleh bank.

Sehingga menurut penulis, prinsip kerahasiaan bank merupakan penghambat dalam proses penegakkan hukum, karena meskipun bisa dibuka, tapi tetap membutuhkan suatu prosedur khusus. Hal tersebut, akan membutuhkan banyak waktu, sehingga proses penyelesaian suatu kasus pencucian uang, akan lebih lambat. 
Namun meskipun kerahasiaan bank merupakan hambatan dalam penegakkan suatu kasus pencucian uang. Akan tetapi, penegak hukum juga harus tetap menghormati prinsip tersebut. Hal itu dikarenakan prinsip kerahasiaan bank merupakan hal yang sangat penting dalam suatu sistem perbankan, mengingat sistem perbankan didasarkan pada kepercayaan masyarakat. Oleh karena itu, penegak hukum ketika melakukan tugasnya, harus tetap patuh pada prosedur pembukaan rahasia bank sebagaimana yang telah ditentukan oleh Undang-undang.

\section{PENUTUP}

1. Adanya prinsip kerahasiaan bank, kemudian semakin ketatnya prinsip tersebut dalam suatu negara, akan menjadi salah satu faktor yang membuat seseorang untuk melakukan pencucian uang dengan menempatkan uangnya pada bank dalam suatu negara, terutama dalam negara yang prinsip rahasia banknya masih sangat ketat. Bahkan dikatakan bahwa semakin ketat sistem kerahasiaan perbankan suatu negara maka semakin sering dipergunakan sebagai sarana melakukan pencucian uang.Ketatnya aturan kerahasian mengenai nasabah dan simpanannya, akan memancing orang yang berniat buruk untuk menggunakan aturan mengenai rahasia bank, demi memperoleh keuntungan. Misalnya untuk menyembunyikan uang atau harta kekayaan yang asal usulnya berasal dari hal yang dilarang oleh Undang-undang atau dari suatu tindak pidana, karena berpikir bahwa prinsip kerahasiaan bank ini akan membantunya menyimpan dan untuk menyamarkan asal usul harta kekayaannya.Uang atau harta kekayaan yang diperoleh dari berbagai tindak pidana tersebut pada umumnya tidak langsung digunakan atau dibelanjakan oleh pelaku, karena apabila langsung digunakan, tentunya sumber dari harta kekayaan tersebut akan mudah dideteksi oleh aparat penegak hukum. Adanya prinsip kerahasiaan bank, telah dimanfaatkan oleh para pelaku tindak pidana pencucian uang untuk menutupi harta hasil kejahatannya. Oleh karena itu, dapat disimpulkan bahwa prinsip kerahasiaan bank memiliki hubungan dengan munculnya suatu kasus pencucian uang. Diketahui bahwa dengan adanya prinsip kerahasiaan bank, maka sistem perbankan dianggap sebagai tempat teraman untuk menempatkan uang hasil tindak pidana tersebut. Pelaku kejahatan akan 
mengusahakan agar harta kekayaan dari hasil tindak pidana terlebih dahulu masuk ke dalam suatu sistim keuangan (financial system) yang sah, dengan tujuan agar harta yang dihasilkan dari tindak pidana tersebut tidak dapat atau sulit untuk dilacak oleh aparat penegak hukum.

2. Prinsip kerahasiaan bank merupakan penghambat dalam proses penegakkan hukum, karena meskipun bisa dibuka, tapi tetap membutuhkan suatu prosedur khusus. Kemudian proses tersebut, tentuyaakan membutuhkan waktu tambahan, sehingga proses penyelesaian suatu kasus pencucian uang, akan lebih lambat.Namun meskipun kerahasiaan bank merupakan hambatan dalam penegakkan suatu kasus pencucian uang. Akan tetapi, penegak hukum juga harus tetap menghormati prinsip tersebut. Hal itu dikarenakan prinsip kerahasiaan bank merupakan hal yang sangat penting dalam suatu sistem perbankan, mengingat sistem perbankan didasarkan pada kepercayaan masyarakat. Oleh karena itu, penegak hukum ketika melakukan tugasnya, harus tetap patuh pada prosedur pembukaan rahasia bank sebagaimana yang telah ditentukan oleh Undang-undang.

\section{DAFTAR PUSTAKA}

Amrullah, M. arief,Tindak Pidana Pencucian Uang Money Loundering, (Malang: Bayu Media Publishing, 2004

Anwar, Moch, Tindak Pidana di Bidang Perbankan, Bandung: Alumni, 1986.

Arrasjid, Chainur,Dasar-Dasar Ilmu Hukum, Jakarta: Sinar Grafika, 2000.

Djumhana, Muhamad, Rahasia Bank (Ketentuan dan Penerapannya di Indonesia), Bandung: PT Citra Aditya Bakti, 1966.

-, Hukum Perbankan Indonesia, (Bandung: PT. Citra Aditya

Bakti, 2006

Asas-Asas Hukum Perbankan Indonesia, Bandung: PT.Citra

Aditya Bakti, 2008.

Fuady, Munir, Hukum Perbankan Modern, Bandung: PT Citra Adiyta Bakti, 2001.

Husein, Yunus, Rahasia Bank: Privasi Versus Kepentingan Umum, Jakarta: Pascasarjana Fakultas Hukum Universitas Indonesia,2003.

Siahaan, NHT, Pencucian Uang dan Kejahatan Perbankan, Jakarta: Pustaka Sinar Harapan, 2005. 
Susilo, Y. Sri, Sigit Triandaru, dan A.Totok Budi Santoso, Bank dan Lembaga Keuangan Lainnya, Jakarta: Salemba Empat, 2000.

Sutedi, Adrian, Tindak Pidana Pencucian Uang, Bandung: PT.Citra Aditya Bakti, 2008. ,Hukum Perbankan Suatu Tinjauan Pencucian Uang, Merger, Likuidasi, dan Kepailitan, Jakarta: Sinar Grafika, 2010.

Zainal, Asikin, Pokok-Pokok Hukum Perbankan di Indonesia, Jakarta: PT Raja Grafindo Persada, 1995.

Indonesia, Pencegahan dan Pemberantasan Tindak Pidana Pencucian Uang, Undangundang No. 8 Tahun 2010, LN No. 122 Tahun 2010, TLN No. 5164.

Damanik, Jenriswandi,Tindak Pidana Pencucian Uang dan Penegakan Hukumnya, Medan: Universitas Simalungun, 2014. Diakses dari USI.ac.id, Pada Tanggal 25 November 2015.

Husein, Yunus,Kebijakan Bank Indonesia tentang Money Laundering, Disampaikan dalam rangka Seminar Undang-Undang Nomor 15 Tahun 2002 Tentang Tindak Pidana Pencucian Uang, diselenggarakan oleh Lembaga Info Naker, Jakarta: 27 Juni 2002. Diakses dari https://yunushusein.files.wordpress.com, Pada tanggal 25 November 2015

Wardhani, Anita Tiar Kusuma,Studi Perbandingan Tentang Pengaturan Pemberian Perlindungan Saksi Dalam Undang-Undang Tindak Pidana Pencucian Uang Di Negara Indonesia Dan Malaysia, (Surakarta: Universitas Sebelas Maret, 2008. Diakses dari digilibs.uns.ac.id, Pada Tanggal 25 November 2015.

Purwadi, Ari, Jasa Private Banking Pada Lembaga Perbankan Sebagai Sasaran Dan Sarana Pencucian Uang, Surabaya: Universitas Wijaya Kusuma, 2012. Diakses dari ejurnal.uwks.ac.id, Pada Tanggal 25 November 2015.

Rifai, Eddy,Pembukaan Rahasia Bank Untuk Kepentingan Peradilan dalam Perkara Pidana, Lampung: Universitas Lampung, 2012. Diakses dari staff.unila.ac.id, Pada Tanggal 25 November 2015.

Sukawati, Anak Agung Istri Chandra Pramita, Pengaturan Kewajiban Bank Menjaga Kerahasiaan Data Nasabah Penyimpan Menurut Undang-Undang Perbankan, Bali: Tesis Universitas Udayana, 2015. Diakses dari www.pps.unud.ac.id, Pada tanggal 25 November 2015. 
Sjahdeini, Sutan Remy, Rahasia Bank: Berbagai Masalah Disekitarnya, Makalah ini disajikan sebagai bahan diskusi mengenai legal isues seputar Pengaturan Rahasia Bank, Jakarta: Bank Indonesia, Senin 13 Juni 2005. Diakses dari www.oocities.org, Pada tanggal 25 November 2015.

Swastika, Benny,Tinjauan Hukum Asas Pembuktian Terbalik dalam TIndak Pidana Pencucia Uang, Jakarta: Universitas Indonesia, 2011. Diakses dari lib.ui.ac.id, Pada Tanggal 25 November 2015.

Tajudin, I,Analisis Yuridis terhadap Pembukaan Rahasia Bank (Lifting Bank Secrecy) Dikaitkan dengan Undang-Undang 15 Tahun 2002 Tentang Tindak Pidana Pencucian Uang (Money Laundering) Sebagaimana Telah Diubah Dengan Undang-Undang Nomor 25 Tahun 2003, Bandung: Universitas Padjajaran, 2009.

Winarni, Eka, Studi Komparasi Hukum Pengaturan Konsep Pembukaan Rahasia Bank Dalam Penyidikan Perkara Money Laundering Menurut UU No. 25 Tahun 2003 Tentang Tindak Pidana Pencucian Uang Dengan Republic Of The Philippines Code No.9160 On Anti Money Laundering Act Of 2001, Surakarta: Universitas Sebelas Maret, 2010. Diakses dari http://core.ac.uk/, Pada Tanggal 25 November 2015. 